\section{The structure of Newgrange}

The writer of this note, Mr Henning Nelms, Box 7066, Arlington, Virginia 22207, wrote to the Editor recently saying, "Your article in the Fuly "Scientific American" repeats the statement that the dome of Newgrange is corbelled.' We are more than happy to be corrected in a long-held belief, and urged Mr Nelms to give us a short illustrated note on his ideas of the amazing durability of the great central roofed structure in Newgrange.

Although the great chamber at Newgrange is often described as 'corbelled', it actually differs from a corbelled structure in almost every possible way. Both types use capstones to keep out dirt and water. Apart from this there is no resemblance.

Corbelling is primarily suited to arches (FIG. $\mathrm{I} a$ ). It can be adapted to domes, but this raises problems and requires experienced builders. The procedure followed at Newgrange is restricted to domes (FIG. I $b$ ). It cannot be used to form arches.

Corbelling is not strictly 'megalithic' as it employs stones of moderate size. These stones must be flat. Unless naturally flat slabs are available, the top and bottom of each stone must be worked to create smooth planes. Each stone is laid on the stone below it, so that one end projects slightly. These projections make one side of the arch. A corresponding structure on the other side completes the arch.

Additional stability is created by the fact that the top stones on the two sides of the arch press against each other. Earth or rubble piled on the stones keeps them from tilting and also adds to the stability. Even so, this is precarious. If the soil under the foundation settles or is washed away the arch may collapse. This can also happen if roots destroy the alignment of the stones, or if there is a mild earthquake.

The method used at Newgrange is literally megalithic; the lower members must be huge if the dome is to be of any size. Each member needs to be chipped to form a crude cylinder or prism, but no further working is needed, or even desirable. The foundation stones are arranged to create a polygon. Each stone of the next course is placed so that its ends are supported by the middles of the stones below it. The same method is followed for the remaining courses. The only difference is that the stones get progressively shorter as the work progresses. As you can see from FIG. $x b$, each stone acts both as a beam and as part of the wall. The
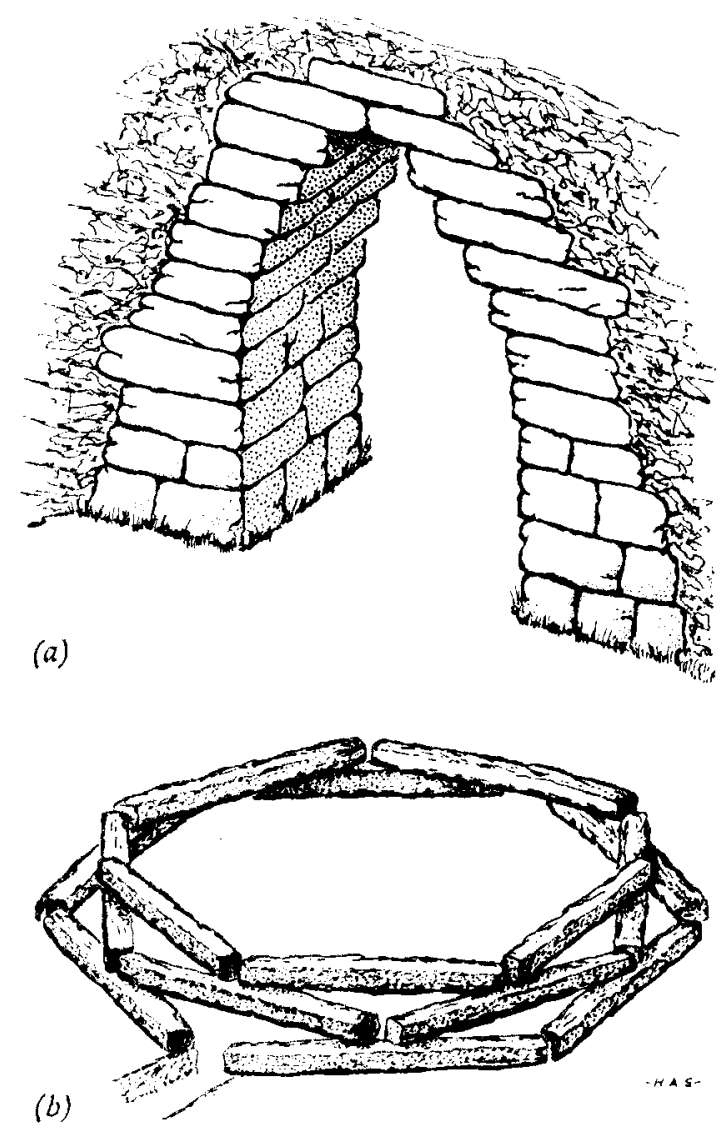

Fig. I, a: Corbelled arch. Note vertical piers used to increase height without increasing breadth. Corbelling can be employed for domes. However, the construction is much more complex, and cannot be made so clear in an illustration. b: Beam-wall construction used at Newgrange. Only the first two courses and part of the third are shown. Completing the structure would have concealed the interior. The individual members have been smoothed, both for simplicity and to stress their likeness to logs. The stones used at Newgrange are much more rugged. The earth piled on Newgrange is not indicated as it serves no structural function

method may therefore be called 'beam-wall' construction.

Although earth was piled on Newgrange, it does not increase the stability. In fact, a beam-wall structure is almost as permanent as a pyramid. Unless a stone breaks, or a root pushes one end of a stone off the one below it, or excavators remove the stones one by one, Newgrange will last forever.

Beam-walled domes can be distinguished from 
corbelled domes at a glance. Anyone standing inside a beam-walled dome sees the sides of the stones. Large areas of the tops and bottoms will also be visible, but the ends will be more or less hidden. An observer in a corbelled dome sees only the ends of the stones and small strips of their lower sides.

Theoretically, a corbelled structure can be of any size. Actually, the width is restricted, because any increase in width also increases the danger of collapse. No such limitation applies to height. If a vertical wall is used as a base, any desired height can be achieved (FIG. $1 a$ ).

By contrast, the size of a beam-wall dome is fixed by the lengths of the stones used for the foundation. Some increase may be gained by adding more sides to the basic polygon. This, however, cannot be carried far. Unless the angles at the corners are fairly sharp, the method ceases to be practical.

All of these differences can be demonstrated by using dominoes to build a model of a corbelled arch and lead pencils or bits of dowel to build a beamwall dome.

A friend tells me that Navajo Amerinds of New Mexico use beam-wall construction to build their hogans (huts). They then cover the logs with mud to keep out draughts and the occasional showers of their nearly waterless country. In this case, the mud has a structural function. The logs are so small that they might be displaced by a strong wind if they were not protected in some way.

The possibility of wood construction may be of interest to archaeologists. Corbelling requires stone or, conceivably, brick. It cannot be done with timber. Beam-wall construction, on the other hand, is ideally suited to the needs of people who prefer to work with logs. When trees with straight trunks are available, they can be felled and trimmed with stone axes. If they are arranged to form a beamwall structure and covered with earth, the result is an imposing mound. It will not be permanent, because it will collapse as the wood decays. Nevertheless, it can be built in much less time than a similar mound composed entirely of earth. Something of the sort may have provided a prototype for Newgrange. This is at least a possibility worth considering. If a dig ever reveals the remains of logs that seem to have been arranged in otherwise meaningless concentric polygons, it may indicate a beam-walled dome.

\section{Strabo IV 4.I: a reference to Hengistbury Head?}

Melinda Mays read Literae Humaniores at St Anne's College, Oxford, and is now working for a D.Phil. on the Durotriges-a social and economic study, with particular reference to coinage-under the supervision of Professor Cunliffe. She took part in his excavations at Hengistbury in 1979 and 1980 , and now comes up with the attractive suggestion that Strabo's emporion in the passage quoted below might have referred to Hengistbury Head.

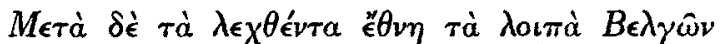

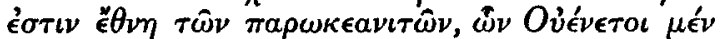

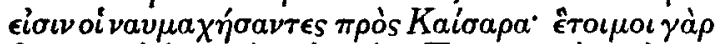

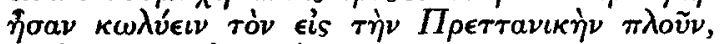

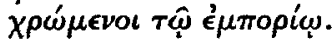

After the aforesaid tribes, the rest are tribes of the Belgae living by the ocean, of which the Veneti are those who fought at sea against Caesar; for they were prepared to prevent his sailing to Britain, as they were using the trading centre.

Translators of the passage quoted above have generally taken chrömenoi tõ emporiō to mean that the Veneti were using Britain as a place of trade (thus Lasserre I966, I 56: "cette île leur servant de marché'), or have avoided precise definition by using the latinized form of the word emporion (Jones 1960, 235: 'since they were using the emporium there'). Strabo does not name the emporion, and it is for this reason that the phrase has been taken in a general sense, despite the presence of the definite article $t o$.

I would like to suggest first that to emporion refers to a specific trading centre, rather than to Britain in general, and secondly that a likely candidate for this centre is Hengistbury Head, Dorset (formerly Hampshire). To this end I will discuss the use of the word emporion, particularly in Strabo, and will give an outline of Strabo's sources for this passage, and of the archaeological evidence for: such an emporion in Britain.

\section{Use of the word 'emporion'}

Emporion is defined as a trading centre, referring either to a city (or town, if it does not rank as a polis), or to a particular quarter of that city. Stephanus (1865) defines it as 'Urbis locus in quo mercaturae et negotiationes exercentur, praesertim in portu situs'. 